\title{
機械ごてによるコンクリート直仕上げ床の施工条件判定のための コンクリート性状の測定方法に関する研究

\author{
METHOD OF MEASURING CONCRETE PROPERTIES FOR JUDGING \\ FINISHING CONDITIONS OF MONOLITHIC CONCRETE FLOOR \\ AT MECHANICAL TROWELLING
} \\ 三上貴 正*, 早野博 幸**, 小野英哲*** \\ Takamasa MIKAMI, Hiroyuki HAYANO and Hidenori ONO
}

\begin{abstract}
Experiments on mechanical trowel finishing were performed with ten kinds of concretes under two trowelling conditions, in order to examine the influence of concrete properties on floor finishing.

In the experiments, the configuration of concrete surface was measured before and after trowelling.

Dynamic reaction on trowel and penetration resistance were also measured as rheological properties of concrete

at the time of trowelling.

As a result, a trial method for measuring concrete properties and for judging finishing conditions of concrete floor was proved by using dynamic reaction and configuration of concrete surface at mechanical trowel finishing.
\end{abstract}

\author{
Keywords : concrete floor of monolithic finishing, mechanical trowel finishing, properties of concrete, \\ method of measurement, dynamic reaction on trowel, configuration \\ コンクリート直仕上げ床, 機械ごて仕上げ, コンクリート性状, 測定方法, こて反力, 表面形状
}

\section{1. 序論}

前報 ${ }^{1)}$ では，本研究の背景として，機械ごてによるコ ンクリート直仕上げ床（以後，単に直床と記す）の仕上 げ作業が近年行われるようになっていること六 尕，また その際の課題として，最適こて仕様の設定方法や作業開 始時期の判定方法の開発などが必要であること ${ }^{5) （ 8)}$ を述 べた。さらに前報では，上記の課題を検討するための第 1 段階として, 直床の仕上りに及ぼす機械ごての仕様お よびコンクリート性状の影響の基本的傾向を実験的に明 らかにするとともに，これらの影響の定量化の可能性を 示した。

本報では，前報に引き続き，上記の課題を検討する際 に必要となるこて仕上げの観点からのコンクリート性状 の定量化に関し、さらに考察を加えた結果について報告 する。

\section{2. 研究の目的と範囲}

本研究は，機械施工による直床を対象として，仕上げ 時のコンクリート性状と直床の仕上りとの関係の考察か ら，こて仕上げの観点からのコンクリート性状の測定方 法を提示するとともに，本測定方法に基つくく最適施工条 件の試行的判定を行い，その妥当性を検討することを目 的とする。

なお，直床の仕上げ作業は，広義には床面の平坦化の 工程である均し作業と，平滑化の工程であるこて仕上げ 作業からなるが，本研究では前報に引き続き後者を主対 象として研究を行うこととする。また，直床の仕上りに 関しても，前報と同様に表面形状の観点からの仕上りに 研究对象を限定し, 表首強度など他の観点からの検討は 今後の課題とする。さらに, 本研究ではコンクリート性 状の定量化に関する検討を研究の主たる範囲とし、コン クリート性状との関連で決定すると想定される最適施工 条件に関しては，作業開始時期およびこてかけ数の試行

* 東京工業大学大学院情報理工学研究科 情報環境学専攻 助教授・工博

** 日本セメント (株) 中央研究所 (当時東京工業大学大学院生) - 工修

*** 東京工業大学工学部建築学科 教授. 工博
Assoc. Prof., Dept. of Mechanical and Environmental Informatics, Graduate School of Information Science and Eng., Tokyo Institute of Technology, Dr. Eng.

Central Research Laboratory, Nihon Cement Co., Ltd., M. Eng.

Prof., Dept. of Architecture and Building Eng., Faculty of Eng., Tokyo Institute of Technology, Dr. Eng. 
的判定を行うにとどめ，機械ごての最適仕様に関する詳 細な検討は本研究の成果を踏まえたうえで検討すべき今 後の課題とする。

\section{3. 既往の研究}

前報でも述べたように，仕上りに及ぼす仕上げ作業時 のコンクリート性状の影響に関する検討は，その必要性 が認識されながらも若干の基礎実験がなされるにとどま っている ${ }^{2) \sim 6) 。 ~}$

一方, 難波らの左官工事における作業性能に関する研 究においては, 斜め加力レオメータを用いて左官材料の

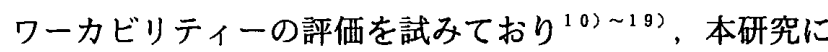
とって有効な示唆を与えるものである。しかし，研究対 象が異なることから，本研究に直ちに適用できる研究成 果は得られていない。

また，筆者らは，前報において仕上りに及ぼすコンク リート性状の影響に関し基礎的考察を行っているが，実 験対象としたコンクリートの性状がやや限定されている こと，また実際の現場にも適用可能なコンクリート性状 の測定方法の提示までには到っていないことなどの課題 が残されている。

\section{4. 研究方法}

本研究における研究方法および手順の概要は, 以下の とおりである。

1) 様々な性状の供試コンクリートに対してこて仕上げ 実験装置による模擬仕上げ実験を行い，各実験条件 における仕上りの程度を測定する。同時に，供試コ ンクリートのフレッシュ時および仕上げ時の性状を 測定する。

2）１）の結果から，コンクリート性状が仕上りに及ぼ す影響を考察し，機械ごて仕上げの観点からのコン クリート性状の測定方法を提示する。

3） 2 ) で提示した測定方法に基つきき，最適施工条件と しての作業開始時期およびこてかけ数の試行的判定 を行い，その妥当性を検討する。

なお，本研究では前報の成果を踏まえ，直床の仕上り の程度を表す表面形状パラメータ，および模擬仕上げ実 験装置は前報と同一のものを用いた。

\section{5. 模提仕上げ実験およびコンクリート性状測定実䀦}

\section{1 実験概要}

本研究では，直床の仕上りに及ぼすコンクリート性状 の影響を考察するため, 直床供試体に対して所定の実験 条件にて機械ごて仕上げを行い，こて仕上げ前後の表面
形状パラメータを測定する模擬仕上げ実験（実験 I ）と， コンクリート性状に関する基礎データの集積を目的とす るコンクリート性状測定実験（実験 II）の 2 系統の実験 を行い，両者の実験結果の対応を検討することとした。 なお，実験 I， II の測定項目の多くは実験精度上厳密に は同一の模擬仕上げ過程において同時に測定するのが望 ましいと考えられるが，本研究では測定系の制約上実験 を2系統に分割して実施した。

\section{2 供試コンクリート}

供試コンクリートは，表 1 に示す材料を使用し，水セ メント比, 骨材種, 混和剤種などを変化させ, 調合要因 およびフレッシュ時や仕上げ時の作業性を前報よりさら に広く考虑した，表 2 に示す 10 種を設定した。本研究で は，近年のコンクリートの多様化を考虑し，フレッシュ 時の流動性や材料分離抵抗性の大きい高強度・高流動系 のコンクリートも研究対象とした。

\section{3 こて仕上げ実験装置}

本研究で用いる機械ごてとして, 前報と同様に, 床仕 上げロボットのこて部をモテル化した図 1 に示すこて仕 上げ実験装置を用いた。

本装置は，一定荷重を載荷しコンクリート面との角度 を固定したこてを、鉛直方向に拘束のない状態で水平方 向に一定の速度で移動させ, 直床供試体表面の仕上げを 行うもので，機械ごての主要因である載荷荷重 F(kgf), 移動速度 $\mathrm{V}(\mathrm{cm} / \mathrm{s})$ ，角度 $\theta\left(^{\circ}\right)$ は実情の範囲をほぼ網羅 できるものである。

実験 I， Iにおける機械ごての仕様としての荷重 F, 速度 $\mathrm{V}$ ，こて角度 $\theta$ の 3 要因の組み合わせは, 前報で各

表 1 使用材料

\begin{tabular}{|c|c|c|c|c|c|c|}
\hline \multirow{3}{*}{ 壳 } & \multirow{2}{*}{ 理 } & \multirow{2}{*}{ 類 } & \multirow{2}{*}{ 比重 } & \multirow{2}{*}{$\begin{array}{c}\text { 王樎強さ } \\
\left(\mathrm{kgf} / \mathrm{cm}^{2}\right)\end{array}$} & \multicolumn{2}{|c|}{ 凝 結 時 間 } \\
\hline & & & & & 始 発 & 終 結 \\
\hline & \multicolumn{2}{|c|}{ 普通ポルトランドとメト } & 3.16 & 417 & $2 \mathrm{~h} 28 \mathrm{~m}$ & $4 \mathrm{~h} 02 \mathrm{~m}$ \\
\hline \multirow[t]{2}{*}{ 骨 } & \multicolumn{2}{|c|}{ का } & $\begin{array}{c}\text { 最大寸法 } \\
\text { (mm) }\end{array}$ & 粗粒率 & 表乾比重 & $\begin{array}{c}\text { 吸水率 } \\
(\%)\end{array}$ \\
\hline & 細骨材 & 山砂 & 2.5 & 2.57 & 2.61 & 1.56 \\
\hline \multirow{2}{*}{ 材 } & \multirow{2}{*}{ 粗骨材 } & 砕石 & 20 & 6.79 & 2.57 & 0.73 \\
\hline & & 川础利 & 20 & 6.57 & 2.56 & 1.35 \\
\hline \multirow{3}{*}{$\begin{array}{l}\text { 混 } \\
\text { 和 } \\
\text { 材 } \\
\text { 料 }\end{array}$} & 記 & 種 & 類 & 記 号 & \multicolumn{2}{|l|}{ 種 } \\
\hline & $\mathrm{A}$ & \multicolumn{2}{|c|}{$\mathrm{AE}$ 減水剂 } & $S$ & \multicolumn{2}{|c|}{ シリカフューム } \\
\hline & $\mathrm{H}$ & \multicolumn{2}{|c|}{ 高性能A E 減水剂 } & $\mathrm{F}$ & 增 & 㓥 \\
\hline
\end{tabular}

表 2 供試コンクリート

\begin{tabular}{|c|c|c|c|c|c|c|c|c|c|c|}
\hline \multirow{2}{*}{ 郡号 } & \multirow{2}{*}{$\begin{array}{l}\text { 混和材料 }^{1)} \\
\mathrm{C} \times(\%)\end{array}$} & \multirow{2}{*}{$\begin{array}{l}\text { 水結合 } \\
\text { 材比( } x)\end{array}$} & \multicolumn{4}{|c|}{ 単位容積重量 $\left(\mathrm{Kg} / \mathrm{m}^{3}\right)$} & \multirow{2}{*}{ 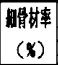 } & \multirow{2}{*}{$\begin{array}{l}\lambda \vec{z} / 7^{\circ} \\
(\mathrm{cdu})\end{array}$} & \multirow{2}{*}{ 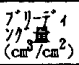 } & \multirow{2}{*}{ fank } \\
\hline & & & 水 & セメット & 細付材 & 柤材材 & & & & \\
\hline P552 & - & 55 & 199 & 360 & 765 & 987 & 43.3 & 16.5 & 0.091 & 221 \\
\hline P553 & $=$ & 55 & 199 & 360 & 765 & 983 & 43.3 & 19.5 & 0.089 & 220 \\
\hline P706 & - & 70 & 179 & 256 & 934 & 953 & 49.1 & 1.0 & 0.066 & 166 \\
\hline H556 & $8: 1.5$ & 55 & 202 & 367 & 869 & 846 & 50.3 & 22.0 & 0.166 & 306 \\
\hline H301 & $B: 2.0$ & 30 & 167 & 553 & 600 & 1049 & 36.1 & 21.5 & 0.000 & 263 \\
\hline H302 & В:2.0 & 30 & 167 & 553 & 788 & 864 & 47.3 & 1.0 & 0.000 & 197 \\
\hline S302 & $\mathrm{H}: 2.0, \mathrm{~S}: 25.0$ & 30 & 167 & 442 & 600 & 1049 & 36.1 & 18.5 & 0.000 & 132 \\
\hline A601 & $A: 0.2$ & 60 & 168 & 280 & 752 & 1064 & 41.0 & 8.0 & 0.075 & 241 \\
\hline F451 & B: $1.5, F: 0.09$ & 45 & 175 & 389 & 682 & 1008 & 40.0 & 26.0 & 0.000 & 267 \\
\hline M551 & - & 55 & 328 & 594 & 1262 & 二 & 100.0 & 24.0 & 0.089 & 223 \\
\hline
\end{tabular}




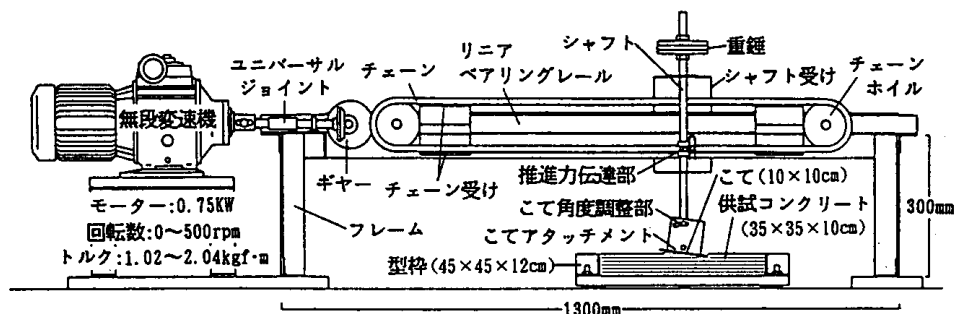

図 1 こて仕上げ実験装置の概要

表 3 実験概要

\begin{tabular}{|c|c|c|c|}
\hline \multirow[b]{2}{*}{ 実 } & & \multicolumn{2}{|c|}{ 模影仕上げ夷験 } \\
\hline & & 実験 I - (1) & 実 験 I - (2) \\
\hline & 実験目的 & $\begin{array}{l}\text { フレッシ時および仕上明時の } \\
\text { コックリート性状の影喓の考察 }\end{array}$ & 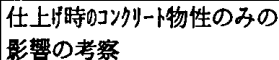 \\
\hline & 目 & \multicolumn{2}{|c|}{ 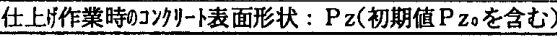 } \\
\hline & & \multicolumn{2}{|c|}{ コンクリート性状测定实験 } \\
\hline & 百 的 & \multicolumn{2}{|c|}{$\begin{array}{l}\text { 実駧 I と対応する仕上け条件におけるコンクリート } \\
\text { 性状に関する基砝テータの集穑 }\end{array}$} \\
\hline & 測 定 項 目 & \multicolumn{2}{|c|}{ 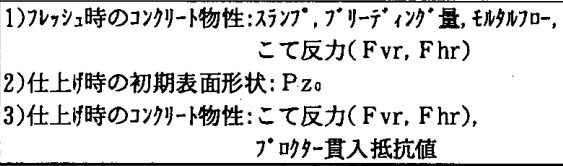 } \\
\hline \multicolumn{2}{|r|}{ コンクリート調合 } & 表2の10調合すべて & 表20P55 \\
\hline \multicolumn{2}{|r|}{ 均 し方法 } & 鋼製ローラー均し1回 & 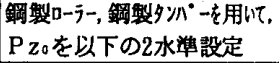 \\
\hline \multicolumn{2}{|r|}{ 均 し程 度 } & 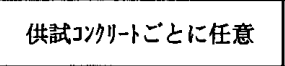 & $\begin{array}{l}\text { 1) } P z_{0}=1 \mathrm{~mm} \text { (目標值) } \\
\text { 2) } P z_{0}=2 \mathrm{~mm} \text { (目標值) }\end{array}$ \\
\hline & \multirow{2}{*}{\begin{tabular}{|l|} 
仕上䍏時間 $\mathrm{T}(\mathrm{h})$ \\
こてかけ数 $\mathrm{N}($ 回 $)$ \\
\end{tabular}} & \multicolumn{2}{|c|}{$3,5,7$ (S302のみ $1,2,3)$} \\
\hline & & \multicolumn{2}{|c|}{$2,4,6,8,10,15,20,25$} \\
\hline & \begin{tabular}{l|l|}
$\Sigma$ & 荷重 $\mathrm{F}(\mathrm{kgf})$ \\
$\tau$ & 速度V $(\mathrm{cm} / \mathrm{s})$ \\
仕 & 角度 $\theta\left(^{\circ}\right)$
\end{tabular} & \multicolumn{2}{|c|}{$\left.\begin{array}{l}\text { 仕様 A (F2, V 30, } \theta 2) \\
\text { 仕様 B (F6, V 30, } \theta 2)\end{array}\right\}$ 計 2 種 } \\
\hline & n & & \\
\hline
\end{tabular}

仕上げ時間ごとに最適となった組み合わせの中から表 3 に示す計 2 種を選定した。

\section{4 仕上りを表示する表面形状パラメータ}

本研究では, 直床の仕上りの程度を表すための表面形 状パラメータとして, 前報において視覚的観点からの妥 当性を検証した $\mathrm{Pz}$ (10点平均粗さ) を選定した。

$\mathrm{P} z$ は, 非接触式変位計を水平方向に走查させて測定し た直床供試体表面の断面曲線から求めた。Pzおよびその 測定・算出の詳細は前報と同様である。

\section{5 模擬仕上げ実験（実験 I）}

前報の結果, 直床の仕上りに及ぼすコンクリート性状 としては, 均しの程度すなわち仕上げ時のコンクリート の初期表面形状, および仕上時のコンクリートのレオロ ジー特性（以後，これをかたさと記す）の 2 要因が重要 であることが明らかとなったことから，本研究ではおも にこれら 2 要因の影響に関してさらに考察することとし， 目的により表 3 に示す 2 種の模擬仕上げ実験（実験 I (1)，I－(2)）を設定した。以下に，実験 I -(1)， I - (2) について説明を加える。

1) 実験 Iー（1)： 仕上りに及ぼす仕上げ時のコンクリ 一トの初期表面形状とかたさの複合した影響を考察する ことを目的とし，表面形状，かたさともに実験の変動要 とした。

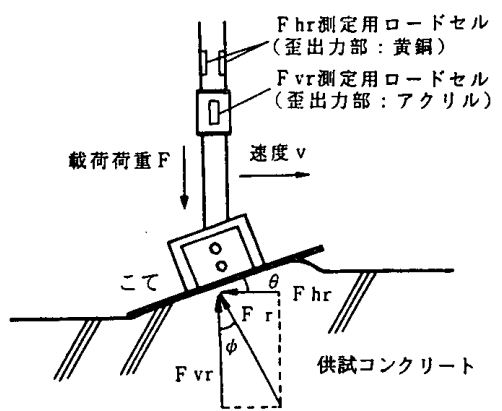

図 2 こて反力測定の概要

因とした。さらに, 実験 I ー-11では均しゃ仕上りの程度 に及ぼすフレッシュ時のコンクリート性状の影響も考察 することとした。供試コンクリートは表 2 の10種全種, 均し方法はすへての供試コンクリートに共通の表 3 に示 す 1 種とした。

2) 実験 I - (2) ： 仕上りに及ぼす仕上げ時のコンクリ 一トのかたさのみの影響を考察することを目的とし，仕 上げ時の初期表面形状をほぼ同一に制御し，かたさのみ を実験の変動要因とした。供試コンクリートは表 2 の中 から表 3 に示す調合要因上基本的な 3 種を選定した。仕 上げ前のコンクリートの初期表面形状はタンパー, 鐝製 ローラーを用いて制御し，その目標値としていずれの調 合に関しても表 3 に示す共通の 2 水準を設定した。

3）実験手順 ： 練り混ぜ終了後, 供試コンクリートを 型枠に打設して所定の均しを施し，その後所定の仕上げ 時間（混練後, 仕上げ作業を開始するまでの時間）まで 盖生の後, 均しの程度を表す $\mathrm{Pz}$ の初期値 $\mathrm{P} \mathrm{z}_{0}$ を測定し, 図 1 に示したこて仕上げ実駼装置を用いて仕上げを施し た。所定回数のこてかけ後，Pzを測定し，さらにこれを 繰り返して機械仕上げによるP zの変化を求めた。以上の 混練から模擬仕上げまでの一連の実験は，すべて恒温恒 湿実験室内 $\left(20^{\circ} \mathrm{C}, 60 \% \mathrm{RH}\right)$ で行った。

5.6 コンクリート性状測定実験（実験 II）

実験 IIでは，仕上りに関連するコンクリート性状とし て下記の項目の測定を行った。

1) フレッシュ時のコンクリート物性の測定 ： フレッ シュ時のコンクリート物性の特性値として, 本研究では スランプ(JIS A 1101), ブリーディング量(JIS A 1123), および供試体コンクリートのモルタル部分のモルタルフ ロー（JIS R 5201）を測定した。さらに, フレッシュ時 の特性値として, 下記の2), b)に示す方法と同様にして, 打設後の均し時におけるこて反力の測定も行った。

2）仕上げ時のコンクリート性状の測定

a）コンクリートの初期表面形状の測定 ： 前報と同様 に初期表面形状を $\mathrm{P}$ Zの初期值 $\mathrm{P} \mathrm{z}_{0}$ として把握すること

b）コンクリートのかたさの測定 ： 前報では，かたさ の試行的測定として,ケリーボール試験法（ASTH C360） 
およびプロクター貫入抵抗試験法（ASTM C403）を準用し て種々の貫入抵抗值を求め, $\mathrm{P} z$ の最小值 $\mathrm{P} z \min$ との対応 を考察した。その結果, ケリーボール試験による $10 \mathrm{~mm}$ 貫 入時荷重量 $\left(\mathrm{K} \mathrm{B}_{10}\right)$ が P zmin亡比較的明確な対応を示 すことを述べた。しかし，K B 10 に関しては測定時の必 要載荷量が大きく施工現場での測定が困難であることか ら，本研究では施工現場にも適用し得るプロクタ一貫入 抵抗試験（変法）により, 実験 I と対応する各仕上げ時 間におけるコンクリートの貫入抵抗値を测定することと した。

さらに，前報では K B 10 をはじめとする貫入抵抗值と P zminとの対応性が必ずしも十分ではなかったことから， 供試コンクリートの調合をより多様化した本研究におい

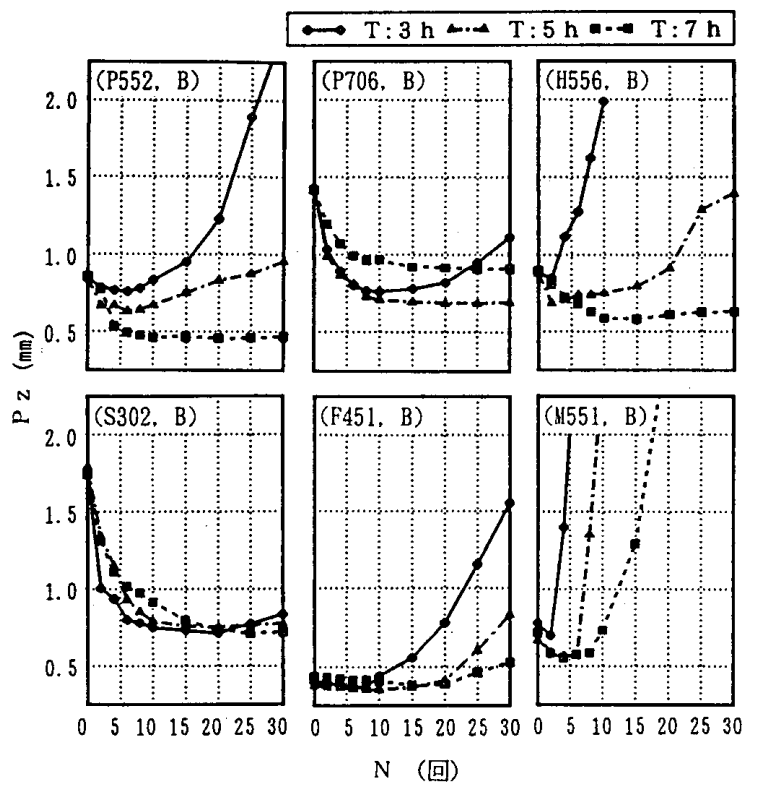

図 $3 \quad \mathrm{Pz}$ とこてかけ数の関係の例（実験 I - (1)

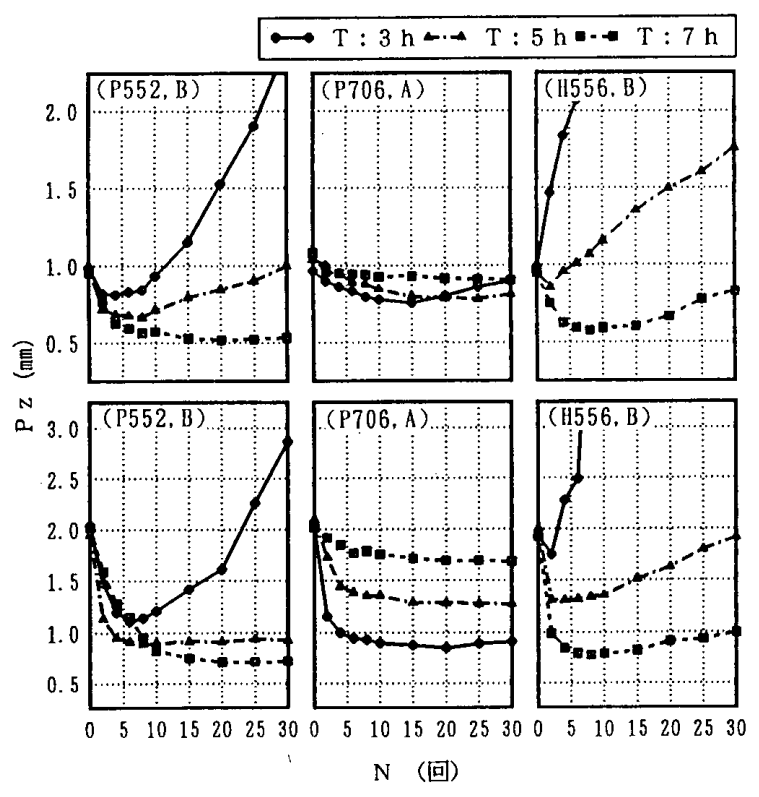

図 $4 \quad \mathrm{P} z$ とこてかけ数の関係の例（実験 I - (2)）
ては，こて仕上げ作業中における力学的状況を可能な限 り忠実に考察するという立場から，難波らの左官材料の ワーカビリティーに関する研究 ${ }^{10) \sim 19)}$ における斜め加力 レオメータを参考として，仕上げ時のコンクリートのか たさをこて面に作用する荷重 (以後, こて反力と記す) により把握することとした。こて反力の測定においては, 図 2 に示すように実験装置のこてのシャフト部に 2 軸の ロードセルを設け，実験 I と同一の実験条件下において コンクリートから受ける鉛直こて反力 Fvr（kgf），水平 こて反力F hr（kgf）をそれぞれ測定した。

\section{7 実験結果および基本的考察}

以上に説明した実験 I , II の結果の対応等に関する詳細 な考察は次節 6 。以降に記すこととし，ここでは夷験 I, II の結果の例およびそれらに関する基本的考察を示す。

1）実験 I の結果および考察

図 3 に, 実験 I - (1)の結果得られた Pzここてかけ数 $\mathrm{N}$ の関係の例を示す。図から, 前報同様, $\mathrm{P} z$ の初期値 $\mathrm{P} z$ oは調合により様々な值をとること, また調合, 仕上 げ時間により P zの最小值 P zmin（仕上りの最良值）, $\mathrm{P}_{2}$ と $\mathrm{P} z \min$ の差（仕上げの効果），および $\mathrm{P} \mathrm{Z}_{0}$ から P zminまでに要するこてかけ数（最適こてかけ数。以後, $\mathrm{Nb}$ b記す）は，それぞれ異なることが確認できる。

次に, 図 4 に実験 I - (2)の結果得られた P Zとこてかけ 数 Nの関係の例を示す。実験 I - (2)では $\mathrm{P} z_{0}$ を制御し 2 水準設定したが, 図からこて仕様と仕上げ時間の条件に よっては, P zoの水準が異なってもP zminはほぼ同程度 まで小さくなることがわかる。

2）実験 】の結果および考察

ここでは実験 II の結果のうち, 特にこて反力の測定結 果を示す。

図 5 は，こて仕上げ実験装置を用いて測定したこて反 力の測定結果の一例である。図からわかるように, 直床 供試体表面とこての接触しているこて仕上げ中の動的こ て反力は，鉛直分力，水平分力ともにほぼ一定值である ことから, 本研究で以降用いるこて反力として，こての

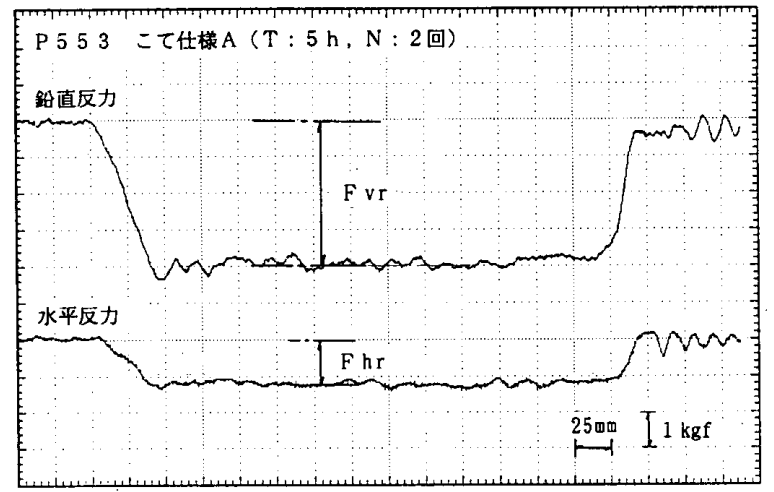

図 5 こて反力の測定結果の一例 


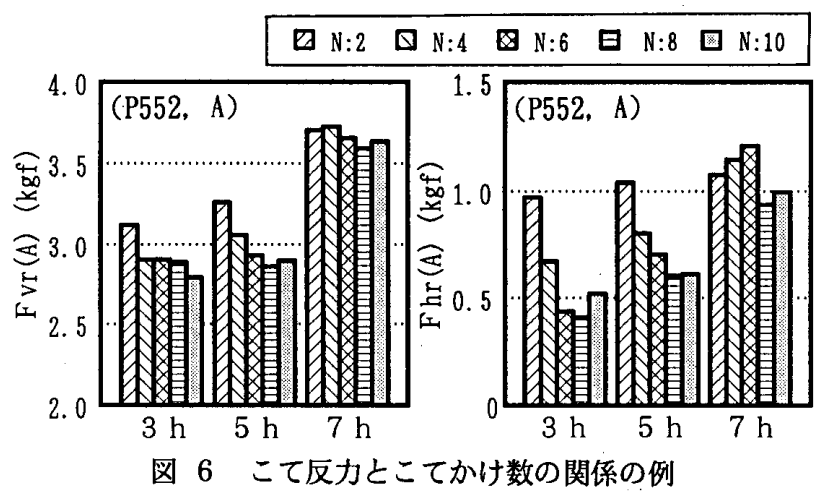

接触している区間中の鉛直こて反力および水平こて反力 の平均值 (以後, $\mathrm{Fvr}, \mathrm{Fhr}$ と記す) を求めた。

次に，図 6 に上記のようにして求めたこて反力とこて かけ数 $\mathrm{N}$ との関係の例を示す。図から，仕上げ時間，反 力方向により，こてかけ数によるこて反力の変動の傾向 が異なること，ただしこてかけ数がおよそ 6 回以上にな ると変動幅が小さくなること，がわかる。そこで本研究 では以降の考察に用いるこて反力 Fvr, Fhrの值として, それぞれこてかけ数10回までの平均值を求めた。

\section{6. 直床の仕上りに及ぼすコンクリート性状の影溉の考} 察および仕上げの観点からみたコンクリート性状の 測定方法に関する検討

6.1 フレッシュ時のコンクリート物性の影響に関する考 察

6.1 .1 仕上げ時の初期平面形状に及ぼすコンクリート物 性の影響の考察

図7に, 実験 I - (1)の結果得られた仕上げ時の初期表面 形状 $\mathrm{P} z_{0}$ と，実験 II 結果得られたフレッシュ時のコン クリートの各特性値との対応の例を示す。

図 7 (左図)は，P Z 0 とスランプとの対応である。図か ら，全体としてスランプ值の大きい軟練りの調合ほど $\mathrm{P} \mathrm{z}_{0}$ も小さくなる傾向が見受けられるが，粘性の高い調 合（H301，S302）が対応関係からはずれる傾向にあり， 対応性は十分とはいえない。また，ブリーディング量, モルタルフローに関しても十分な対応は得られなかった。

図 7 (中図)は, $\mathrm{P} z_{0}$ とフレッシュ時のコンクリートの 鉛直こて反力 $\mathrm{Fvr}$ との対応である。図から，両者の対応 はスランプの場合と比較して明確であり，F vrが小さい ほどP $z_{0}$ も小くなることがわかる。従って，本研究で 対象とした均し方法の範囲では，F vrにより均し作業の 観点からのコンクリート物性の定量化が可能であること がわかる。

図 7 (右図)は，P $z_{0}$ とフレッシュ時のコンクリートの 水平こて反力 $\mathrm{F} \mathrm{hr}$ との対応である。図から，両者の対応 は不明確であり，粘性の高い調合やブリーディングの多

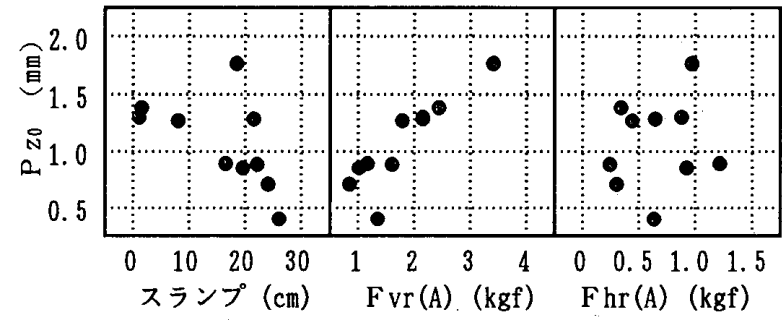

図 $7 \quad \mathrm{P} z$ と とフレッシュ時の特性值との対応の例

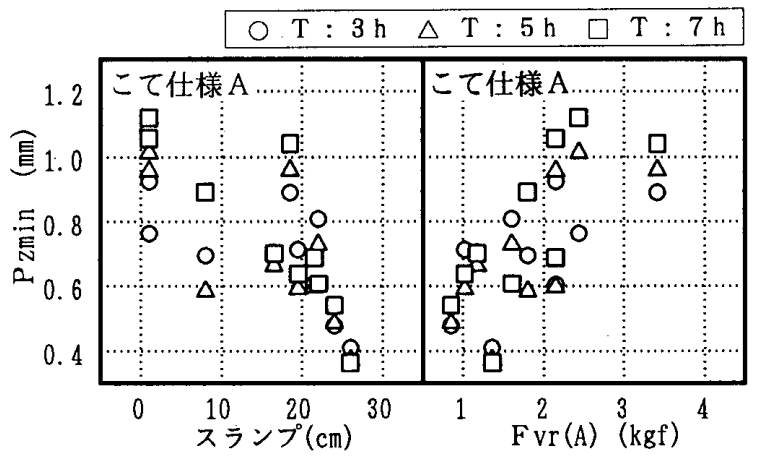

図 8 P zminとフレッシュ時の特性値との対応の例

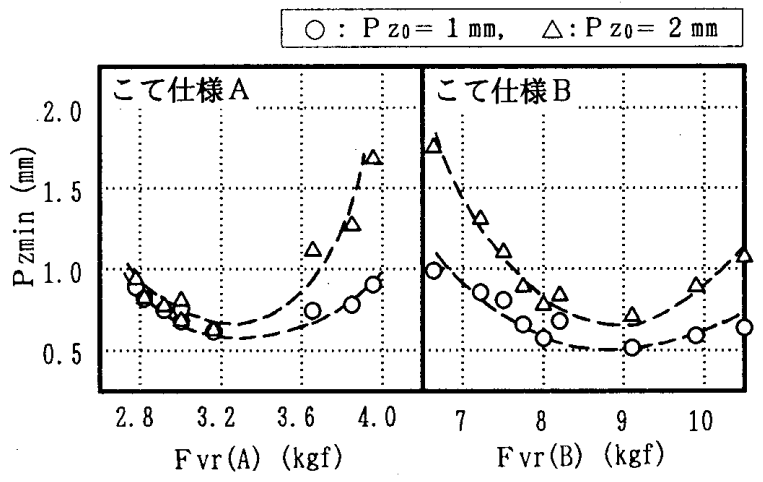

図 9 Pzminとこて反力との対応の例

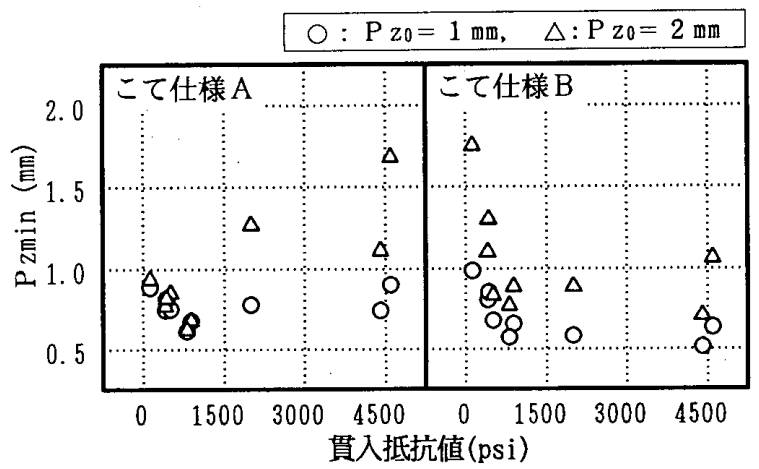

図 $10 \quad P$ zminと貫入抵抗值との対応

い調合も研究対象に含めた本研究においては, フレッシ ユ時の F hrとFvrの相関性は低く，異なる傾向を示すこ とがわかる。

6.1 .2 仕上りに及ぼすコンクリート物性の影響の考察

図 8 に，実験 I-11の結果得られた仕上りの指標であ るP zminと, フレッシュ時のコンクリートの特性值との 対応の例を示す。

図 8 (左図)は, 仕上げ時間ごとのP zminとスランプと 


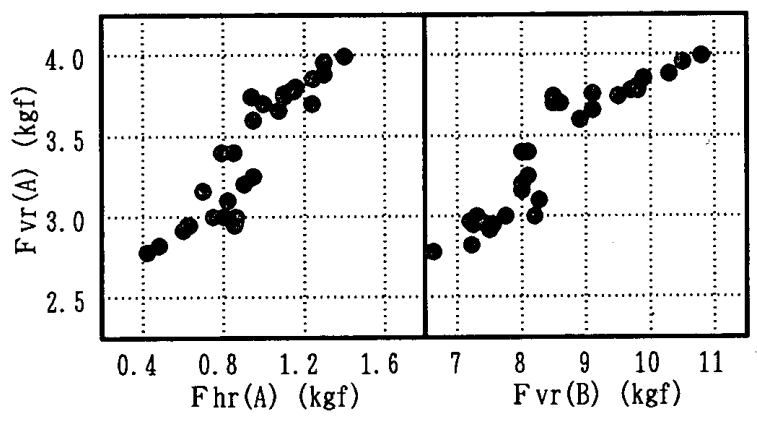

図 11 こて反力相互の対応の例

の対応である。図から、いずれの仕上げ時間に関しても 両者の対応は不十分であることがわかる。

図 8 (右図)は，仕上げ時間ごとのP zminと鉛直こて反 力 Fvrとの対応の例である。図から，Fvrに関しても Pzminとの対応性は高いとはいえず，6.1.1の結果とは異 なり，仕上りに関してはフレッシュ時のコンクリート物 性のみでその程度を説明することは困難であることがわ かる。

6.2 仕上げ時のコンクリート性状の影響に関する考察

6.2.1 仕上りに及ぼすコンクリート物性の影響に関する 考察

図 9，10に，実験 I-(2)の結果得られた $\mathrm{P} z$ min と，実 験 II の結果得られたこて反力およびプロクター貫入抵抗 值との対応を示す。

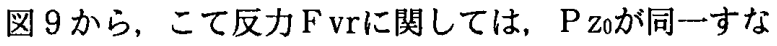
わち均し程度が同一であれば，調合や仕上げ時間に関わ らず F vrはP zminc 2 次関数的な明確な対応関係を示し, 従って F vrによりこて仕上げの観点からのコンクリート 物性の定量化が可能であることがわかる。また，両者の 関係に基づき，こて仕様ごとに，調合に関わらず仕上り が最も良くなるこて作業開始時期（仕上げ時間）の判定 が可能であるといえる。

一方, 図10から，Pzminと前報で考察対象とした貫入 抵抗値との対応性は, こて反力との対応の場合と比較し て劣ることがわかる。

次に，図11に，同一こて仕様に関する F vrとF hrの対 応，および異なるこて仕様に関する F vr相互の対応を示 す。図から，6.1のフレッシュ時のこて反力の測定結果と は異なり，こて仕上げ時においてはこて仕様, 反力方向 に関わらずこて反力相互の相関は高いことがわかる。さ らに，FvrとFhrの合力（Frと記す）を算出した結果， 本研究の範囲では仕上げ時の F r は F vr と高度の相関性を 有し，いずれを用いても同等の考察結果の得られること が判明した。一方，こて反力と貫入抵抗值との対応性は, 図10の結果からも想定できるように，こて反力相互の対 応性と比較して良くないことが確認された。

以上から，こて仕上げの観点からのコンクリート物性 に関しては，仕上げ時のコンクリートの硬化の程度を表

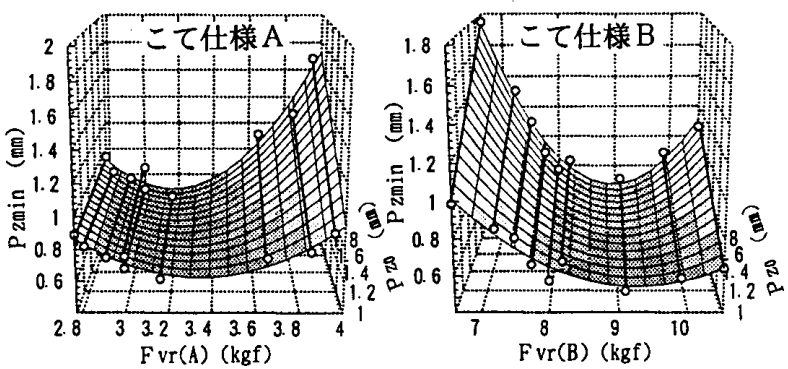

図 $12 \mathrm{Pzmin}, \mathrm{Pz}$ おおよびこて反力の対応の例

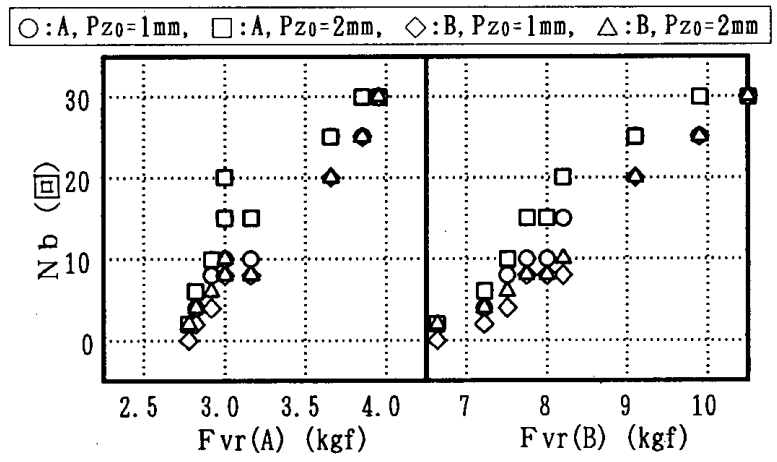

図 $13 \mathrm{Nb}$ ここ反力との対応

す貫入抵抗値による定量化では不十分であり，仕上げ時 のこて反力により定量化すべきことが判明した。

なお，以上の考察から，本研究においてはこて反力に 関する以降の考察は鉛直こて反力 F vrに関する結果につ いてのみ記すこととする。

\subsection{2 仕上りに及ぼすコンクリート性状の影響の考察}

図12に，こて仕様ごとの P zmin，P $z_{0}$ および F vrの対 応の例を示す。図から，調合，仕上げ時間に関わらず $\mathrm{P} z$ minは $\mathrm{P} z_{0}$ とほぼ直線的な関係にあること, 同時に, F vrとは6.2.1でも考察したように 2 次関数的な関係にあ ることが確認できる。

\subsection{3 最適こてかけ数に及ぼすコンクリート性状の影響 の考察}

図13に，実験 I - (2)の結果得られた，Pzminにおける

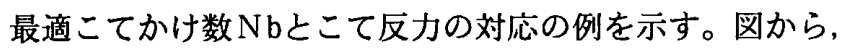
$\mathrm{Nb}$ はこて仕様および初期表面形状 $\mathrm{P} \mathrm{z}_{0}$ ごとにこて反力 とほぼ比例的な関係にあり，こて反力が大きくなるほど 必要なこてかけ数も大きくなることがわかる。

6.3 こて仕上げの観点からみたコンクリート性状の測定 方法の提示

6.2の考察結果から，こて仕上げの観点からのコンクリ 一ト性状は仕上げ時のコンクリートの初期表面形状, お よび仕上げ時のコンクリート物性の特性值であるこて反 力により定量化が可能であることが明らかとなったこと から, 本研究では, こて仕上げの観点からみたコンクリ 一ト性状の測定方法として以下の 2 種を提示する。

1）仕上げ時の初期表面形状の測定方法および特性値 表面形状の測定方法の詳細は前報で述へたとおりとし， 
基礎データとして得られる断面曲線から表面形状パラメ 一夕の初期值を算出する。なお，前報および本研究の結 果から，標準的特性值として $P Z_{0}$ を提示する。

2）仕上げ時のコンクリート物性の測定方法および特性値 コンクリート物性の測定方法として，機械ごてのこて 面に作用する動的こて反力を測定し，接触区間中の平均 値を特性値として求める。なお, 本研究の結果, こて反 力測定の際のこてかけ数としては10回程度を標準と考え る。さらに，こて反力測定の際のこて仕様としてのこて 要因 $\mathrm{F}, \mathrm{V}, \theta$ の組み合わせは, 原則として考察対象と する機械ごての仕様と同一にすべきと考える。ただし，

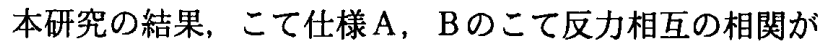
高いことから，実用的にはこて仕様 B（あるいはA）を 標準仕様としても大きな不都合はないと考える。また， 均しの観点からのコンクリート物性の特性值に関する考 察結果を考虑し，標準的特性値としては，鉛直こて反力 F vrを提示する。

\section{7. 直床の最適施工条件の試行的判定に関する検討}

7.1 仕上りの推定および最適こて作業開始時期の試行的 判定に関する検討

6.2.2に示したように, $\mathrm{P} z \min , \mathrm{P} z 0$ および F vrの対 応関係の傾向が明確となったことから，重回帰分析によ りこれらの関係の定量化を試みた。以下に，こて仕様 $\mathrm{A}$ ， BごとにP zminの推定式を, また図14にP zminの実測値 と推定值との対応例を示す。

$\mathrm{Pzmin}=\alpha \mathrm{Pz}_{0}+\beta$

ただし $\mathrm{P}_{Z_{0}}<\beta /(1-\alpha)$ のとき $\mathrm{P}_{\text {zmin }}=\mathrm{P}_{0}$

$\mathrm{A}: \alpha=7.5 \times 10^{-1} \mathrm{~F} \operatorname{vr}(\mathrm{A})^{2}-4.5 \mathrm{~F} \operatorname{vr}(\mathrm{A})+2.3$

$\beta=-2.0 \times 10^{-3} \mathrm{~F} \operatorname{vr}(\mathrm{A})^{2}-5.3 \times 10^{-1} \mathrm{~F} \operatorname{vr}(\mathrm{A})+1.4$

$\mathrm{B}: \alpha=1.3 \times 10^{-1} \mathrm{~F} \operatorname{vr}(\mathrm{B})^{2}-2.2 \mathrm{Fvr}(\mathrm{B})+9.9$

$\beta=-5.8 \times 10^{-2} \mathrm{Fvr}(\mathrm{B})^{2}+9.6 \times 10^{-1} \mathrm{Fvr}(\mathrm{B})-3.5$

図14から，Pzminの実測値と推定值は良好な対応を示 すことが明らかで, こて仕様ごとの仕上り P zminは，仕 上げ時の初期形状 $\mathrm{P} z_{0}$ およびこて反力 $\mathrm{F}$ vrによって説明 可能であることがわかる。

次に, 図15に上記の $\mathrm{P}$ zminの推定式に基づく $\mathrm{P}$ zo別に みた $\mathrm{P}$ zminとこて反力 $\mathrm{F}$ vrの対応の例を示す。図から，

以下が考察できる。

1）各こて仕様において，初期形状 $\mathrm{P} \mathrm{z}_{0}$ ごとに仕上げに よる効果 $\left(\mathrm{Pz}_{0}-\mathrm{P} z \min \right)$ が最も大きくなるこて反力 の最適値が存在する。また, その值は本研究の範囲で はP $z_{0}$ が小さくなるほど大きい值となる。以上より， こて仕様が定まれば，仕上げ時の初期形状およびこて 反力により最適なこて作業開始時期（仕上げ時間）の

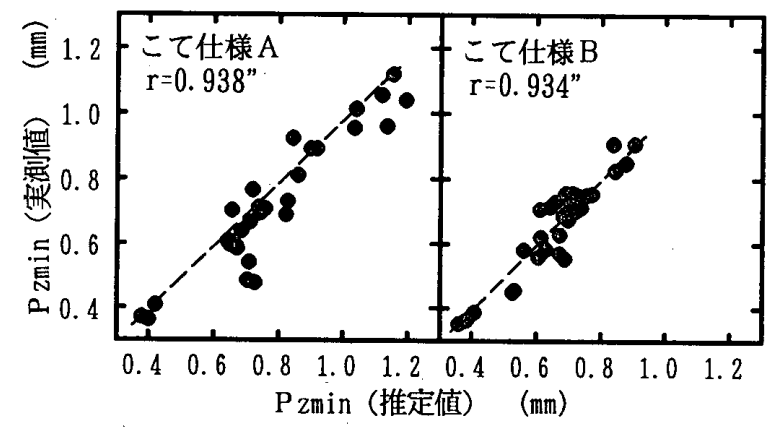

図 14Pzminの実測値と推定值との対応

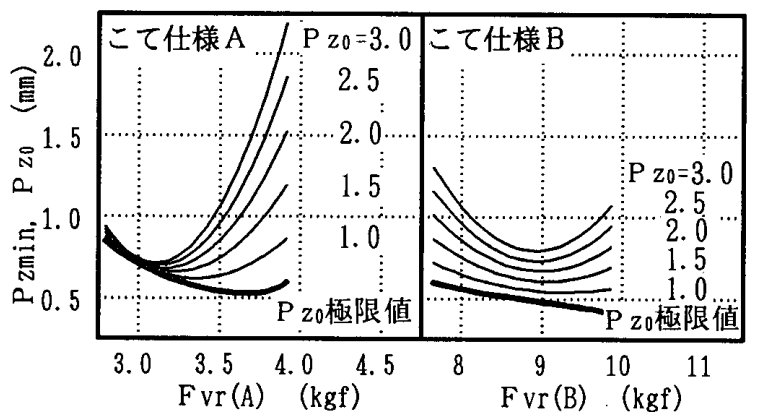

図 15 Pzの推定値とこて反力との対応

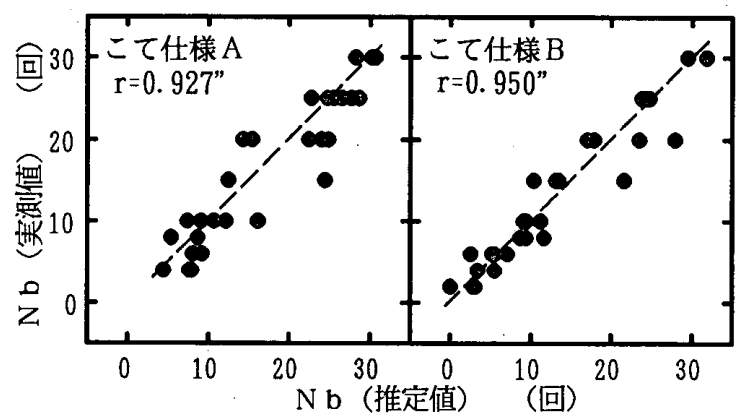

図 $16 \mathrm{Nb}$ 実測値と推定值との対応

判定が可能であるといえる。

2）こて仕様によっては，P Z $Z_{0} に$ 関わらず仕上りがほぼ 同等となるこて反力の範囲が存在する。

3）こて仕様ごとに，こてをかけると仕上りが初期状態よ り悪くなる $\mathrm{P} z_{0}$ の極限值が存在し，その值はこて反力 により推定が可能である。

以上，仕上げ時における初期形状值 $\mathrm{P} \mathrm{z}_{0}$ およびこて 反力 F vrをコンクリート性状の特性値として用いるこ とにより，仕上りの推定が可能であること，また，こ て仕様ごとに，仕上げ時の初期形状およびこて反力を 用いて最適施工条件としての最適なこて作業開始時期 の判定が可能であることがわかる。

7.2 最適こてかけ数の試行的判定に関する検討

6. 2.3に示したように, こて仕様, $\mathrm{P} \mathrm{z}_{0}$ ごとにこて反 力と最適こてかけ数 $\mathrm{Nb}$ 対応関係の傾向が明確となった ことから，7.1と同様に重回㷌分析によりこれらの関係の 定量化を試みた。以下に，こて仕様 $\mathrm{A} ， \mathrm{~B} こ ゙ と に ， \mathrm{Nb}$ 推定式を，また図16に $\mathrm{Nb}$ 実測值と推定值との対応例を 
示す。

$A: \mathrm{Nb}=2.7 \mathrm{P} \mathrm{Z}_{0}+20.9 \mathrm{~F} \operatorname{vr}(\mathrm{A})-55.8$

$\mathrm{B}: \mathrm{Nb}=8.9 \times 10^{-1} \mathrm{Pz}_{0}+8.0 \mathrm{~F} \operatorname{vr}(\mathrm{B})-55.7$

図16から，Nbの実測值と推定値は良好な対応を示すこ とが明らかで，こてかけ数の最適值Nbに関しても，こて 仕様ごとに仕上げ時の初期形状 $\mathrm{P} \mathrm{z}_{0}$ およびこて反力 $\mathrm{F} \mathrm{vr}$ をコンクリート性状の特性值として用いることにより， 最適施工条件としてのNbの判定が可能であることがわか る。

\section{8. 結論}

機械ごてによる直床を対象として，こて仕上げの観点 からのコンクリート性状の测定方法, ならびに本测定方 法に基つく最適施工条件の試行的判定に関して実験的に 考察した本研究の結論は以下のとおりである。

1）機械ごてによる直床の仕上げの観点からみたコンクリ

一ト性状は，仕上げ時の初期表面形状およびこて反力

により定量化が可能であることを示すとともに，これ らの测定・算出方法を提示した。

2）機械施工による直床の均しの観点からみたコンクリー 卜物性は, 均し時の鉛直こて反力により定量化が可能 であることを示した。

3）仕上げ時の初期表面形状およびこて反力をコンクリー 卜性状の特性值として用いることにより，最適施工条 件としてのこて作業の最適開始時期（仕上げ時間）， および最適こてかけ数の判定が可能であることを示し た。

なお，本研究で提示した仕上りPzmin，および最適こ てかけ数Nbに関する推定式はあくまでも本研究で対象と した機械ごての仕様に関してのみ成立するものであり， 異なるこて仕様に関しては，本研究と同様の手続きによ り改めて検討する必要のあることを付記する。さらに, 任意のコンクリート性状に対する最適こて仕様の判定に 関する検討は，本研究の成果を踏まえたうえで行うべき 今後の課題と考える。

\section{考文献}

1）三上貫正，荒川玩也，小野英哲：コンクリート直仕上げ床の仕上りに及 ほす機械ごての仕様およびコンクリート性状の影響の考察，日本建築学 会構造系䄖文埌告集第 453 号, pp. $27 \sim 37,1993.11$

2）山田文三, 斎藤 実, 田中信男, 和美広喜, 新井一彦, 板野弘一 : コン クリート床直仕上げロボットの開発（その1 ロボット開発のための 基礎実験及びロボットシステム)，日本建筑学会大会学術講演梗概集 $\mathrm{A}$, pp. $459 \sim 460, \quad 1985.10$

3）山田文三，斎藤 実，新井一彦，板野弘一：コンクリート床直仕上げロ ボットの開発（その 32 号機の開発と工事への適用結果），日本建策 学会大会学術講演梗概集 A, pp. 653 654, 1987. 10

4）菊池公男，大下俊之，古田周三，今井崇賀：コンクリート床仕上げ用口 ボットの開発と実用化に関する研究，第 1 回建築施エロボットシンポジ ウム論文集, pp. 173 178, 1987.2

5）新井一彦，山田文三，斉藤 実，板野弘一，和美広喜：コンクリート床 直仕上け作業用ロボットの開発とその遒用事例，日本コンクリートエ学 協会フレッシュコンクリートの挙動とその施工への応用に関するシンポ ジウム論文集, pp. 169 174, 1989.4

6）難波蓮太郎：動力こてとと左官ロボットのための新しい左官用回転羽根ご ての開発，日本建箘学会大会学術講演梗概集 A, pp. 901 902，1989. 10

7）青柳隼夫，菊池公男 : コンクリートエ事における現場施工のロボット化 日本コンクリートエ学協会フレッシュコンクリートの挙動とその施工へ の応用に関するシンポジウム論文集，pp. 175 180，1989.4

8）新井一彦：コンクリート床直仕上げ作業の合理化・ロボット化の現状, 建築仕上技術, pp. $52 \sim 55 ， 1991.3$

9）宇治公隆 : コンクリート施工の自動化，機械化に関する最近の研究，コ ンクリートエ学, Vol. 30, No. 2, pp. 46〜49, 1992.2

10）難波蓮太郎，鈴木隆男，鈴木 光：左官工事における作業性能に関する 研究 (その $1 ， そ の 2)$ ，日本建築学会大会学術諢演梗概集（構造系）， pp. $297 \sim 300,1977.10$

11）難波蓮太郎，鈴木隆男：左官工事における作業性能に関する研究（その 3 ，その 4), 日本建筑学会大会学術講演梗概集（構造系），pp. 1 4, 1978.9

12）難波莲太郎，鈴木隆男：左官工事における作業性能に関する研究（その

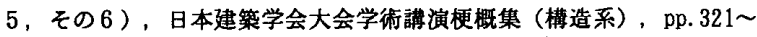
$324, \quad 1979.9$

13）難波蓮太郎，鈴木隆男：左官工事における作業性能に関する研究（その 7 ), 日本建策学会大会学術講演梗概集（構造系）, pp. $379 \sim 380$, 1980.9

14）難波連太郎：左官工事における作業性能に関する研究（その 8 ），日本 建筑学会大会学術諈演梗概集（構造系），pp. $367 \sim 368 ， 1982.10$

15）難波蓮太郎，鈴木慶一：斜目加カレオメー夕による外壁用既調合モルタ ルのワーカビリチーの評価，日本建築学会大会学術講演梗概集 A，pp. 5 $\sim 6,1985.10$

16）難波蓮太郎，鈴木慶一；左官工事における作業性能に関する研究（その 10），日本建築学会大会学術㜔演梗概集 A，pp. 613 614，1986.8

17）難波蓮太郎，鈴木度一：左官工事における作業性能に関する研究（その 11），日本建筑学会大会学術㜔演梗概集 A, pp. 599 600, 1987.10

18）難波蓮太郎：斜め加カレオメー夕による左官材料のワーカビリチー謤価 とその応用、日本建築仕上学会大会学術講演会，pp. 55 58，1992

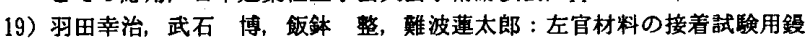
凅り仕上げの提案, 日本建築仕上学会大会学術講演会研究発表論文集, pp. 33 36, 1993.9

(1994 年 7 月 10 日原稿受理, 1994 年 10 月 3 日採用決定) 